\title{
Effects of Haloperidol and Risperidone on Neurotensin Levels in Brain Regions and Neurotensin Efflux in the Ventral Striatum of the Rat
}

Susanne H.M. Gruber, B.Sc., George G. Nomikos, M.D., Ph.D., Aleksander A. Mathé, M.D., Ph.D.

Neurotensin (NT) may play a role in the pathophysiology of schizophrenia and in the mechanism of action of antipsychotic drugs. Here we studied the effects of a 30-day regimen of haloperidol $(1.15 \mathrm{mg} / 100 \mathrm{~g}$ food) and risperidone (1.15 and $2.3 \mathrm{mg} / 100 \mathrm{~g}$ food) on NT-like immunoreactivity (-LI) levels in brain tissue and NT-LI efflux in the ventral striatum (VSTR) of the rat. Haloperidol, but not risperidone, increased NT-LI levels in the striatum. In the occipital cortex, risperidone, but not haloperidol, decreased levels of NT-LI. In the hippocampus and the frontal cortex both haloperidol and risperidone (the higher dose) increased NT-LI levels. In the VSTR, haloperidol and risperidone (the higher dose) decreased NT-LI efflux and abolished the stimulatory effect of d-amphetamine (1.5 $\mathrm{mg} / \mathrm{kg}$, s.c.). Thus, changes in NT occur in response to antipsychotic drugs and psychostimulants that may be relevant for the pathophysiology and treatment of schizophrenia.

[Neuropsychopharmacology 26:595-604, 2002] (C) 2002 American College of Neuropsychopharmacology. Published by Elsevier Science Inc.
KEY WORDS: Neurotensin; Haloperidol; Risperidone; D-Amphetamine; Microdialysis; Rat brain

Neurotensin (NT) is a 13-amino acid peptide originally isolated from hypothalamus (Carraway and Leeman 1973). Several anatomical, behavioral and pharmacological studies have demonstrated an interaction between NT and dopamine (DA) in the central nervous system (CNS). For ex-

From the Institution of Clinical Neuroscience, St. Görans Hospital, S-112 81 Stockholm, Sweden and Institution of Physiology and Pharmacology, Division of Pharmacology, Karolinska Institutet, Stockholm, Sweden (SHMG, AAM), and Eli Lilly \& Company, Lilly Corporate Center, Neuroscience Research Division, (GGN).

Address correspondence to: Aleksander A. Mathé, M.D., Ph.D., Institution of Clinical Neuroscience, Karolinska Institutet, St. Göran \& Hospital, S-112 81, Stockholm, Sweden, Phone: +46-8-672 2343, fax: +46-8-672 4940. E-mail: Aleksander.Mathe@cns.ki.se

Received March 12, 2001; revised September 10, 2001; accepted September 28, 2001.

Online publication: 10/25/01 at www.acnp.org/citations/ Npp102501189. ample, high levels of NT and its binding sites have been found in both the cell body regions, i.e. the substantia nigra pars compacta $(\mathrm{SN})$ and the ventral tegmental area (VTA), as well as the major projection areas of the ascending dopaminergic pathways, i.e. the striatum and the nucleus accumbens (Kasckow and Nemeroff 1991; Lambert et al. 1995; Quirion 1983). Within both the VTA and the $\mathrm{SN}, \mathrm{NT}$ immunoreactive fibers are found in close proximity to DA cell bodies (Hökfelt et al. 1984); within the VTA, NT is colocalized with DA (Hökfelt et al. 1984; Kalivas 1993), while in the striatal complex, the majority of the NT binding sites in rat are located on DA terminals (Cadet et al. 1991). There exists substantial pharmacological evidence showing that NT is involved in the regulation of DA neurotransmission. For example, local perfusion with NT dose-dependently increases striatal extracellular DA levels without affecting DA metabolite levels and modifies the inhibitory effects of DA- $D_{1}$ and DA- $D_{2}$ receptor agonists on striatal DA release (Fuxe et al. 1992). In contrast to the striatum, in the nucleus accumbens direct infu- 
sion of NT does not affect extracellular DA levels, but increases extracellular levels of the DA metabolite homovanillic acid (Chapman et al. 1992). Microinjection of NT into the VTA, produces a dose-dependent in vivo DA release in the nucleus accumbens and also causes a dose-dependent circling behavior (Steinberg et al. 1995). Moreover, blockade of NT receptors by the NT receptor antagonist SR 48692 decreases basal extracellular levels of DA and its metabolites in the nucleus accumbens, suggesting that NT modulates the mesolimbic DA system (Azzi et al. 1998). Neurotensin has also been shown to mimic the effects of neuroleptic drugs in behavioral models of antipsychotic drug action. Thus, centrally injected NT antagonizes psychostimulant-induced locomotor hyperactivity (Ervin et al. 1981; Joliceur et al. 1993; Robledo et al. 1993). These findings support the hypothesis that NT is an endogenous neuroleptic (Nemeroff et al. 1992).

A wealth of evidence also shows that DA neurotransmission modulates NT in the brain (Blaha et al. 1990; Hanson et al. 1989; Levant et al. 1992). For example, administration of cocaine and amphetamine promotes the expression of NT in rat striatum and nucleus accumbens (Betancur et al. 1997; Castel et al. 1994; Merchant et al. 1994b), and methamphetamine elevates NT levels in rat, especially in substantia nigra and striatum (Letter et al. 1987). Neurotensin seems to be regulated both directly and indirectly by DA receptor-mediated mechanisms. Specifically, blockade of $\mathrm{DA}-\mathrm{D}_{2}$ receptors by antipsychotic drugs, as well as DA depletion after 6-OHDA lesion of the nigrostriatal pathway or treatment with reserpine result in an increase in NT levels in the striatum and nucleus accumbens (Merchant et al. 1989). Moreover, selective DA- $\mathrm{D}_{2}$ receptor antagonists raclopride and sulpiride produce an increase in NT mRNA expression in striatum (Augood et al. 1991) and NT content in the caudate (Levant et al. 1991). In addition, typical and atypical antipsychotic drugs induce an increase in NT tissue concentrations in the nucleus accumbens and the caudate nucleus (Kilts et al. 1988; Kinkead et al. 2000). In fact, several studies on the effects of antipsychotic drugs on the NT system have provided evidence in support of the notion of an altered NT neurotransmission in DA-ergic projection regions as an important component of antipsychotic drug action (Huang and Hanson 1997; Merchant and Miller 1994; Radke et al. 1998). Furthermore, Radke et al. (1998) and Kinkead et al. (2000) have reported differential effects of typical and atypical antipsychotics on NT efflux and NT receptor binding in the mesolimbic and the nigrostratial DA-ergic systems that may underlie the differences in the therapeutic profile of these compounds.

Several investigators have measured NT-LI in cerebrospinal fluid (CSF) in schizophrenic patients. Drug-free schizophrenics have been reported to have significantly lower concentrations of NT-LI in their CSF (Lindström et al. 1988). In these patients the CSF NT-LI levels were increased to normal during antipsychotic treatment (Breslin et al. 1994; Sharma et al. 1997; Widerlöv et al. 1982). Therefore, there is an additional clinical interest to study the role of NT in the pathophysiology of psychosis and the mechanism of action of antipsychotic drugs. Abnormal inputs from limbic structures to the ventral striatum have been posited as a model for the pathophysiology of schizophrenia (Bogerts 1999; Csernansky et al. 1991; Grace and Moore 1998; Gray et al. 1991; Weinberger and Lipska 1995) and these regions are therefore of interest in the study of schizophrenia.

To examine the effects of antipsychotic drugs on NT concentrations in the brain, we first determined whether chronic treatment with haloperidol or risperidone under the present experimental conditions affected brain regional NT-LI tissue concentrations. To further understand the interaction between CNS stimulants and NT, we studied whether a single injection of $d$-amphetamine administered to rats pretreated with haloperidol or risperidone affected NT-LI extracellular levels in the VSTR. Results have in part been published in abstract form (Gruber and Mathé 1997).

\section{MATERIALS AND METHODS}

\section{Animals}

Male Wistar rats (B\&K Lab, Sollentuna, Sweden) weighing about $130 \mathrm{~g}$ at the beginning of the experiment were used in all experiments. Animals were maintained in a temperature-controlled room with a 12-h light/dark cycle. The animals were housed five per cage and had free access to food and water. All experimental procedures were approved by the Ethical Committee on Animal Experiments, and the animals were taken care of according to the Karolinska Institutet's Animal Care Guidelines.

\section{Experimental Procedure}

The animals were randomly assigned to either the brain tissue experiment or the microdialysis experiment. In both experiments, haloperidol $(1.15 \mathrm{mg} / 100 \mathrm{~g}$ food, corresponding to approximately $0.7 \mathrm{mg} / \mathrm{kg} /$ day) or risperidone (1.15 or $2.3 \mathrm{mg} / 100 \mathrm{~g}$ food, corresponding to approximately 0.7 or $1.5 \mathrm{mg} / \mathrm{kg} /$ day) was administered for 30 days through food pellets that were prepared by Janssen Pharmaceutica. Control animals were fed with food pellets prepared by Janssen Pharmaceutica. In the brain tissue experiment, 10 animals per group were used, whereas in the microdialysis experiment the number of animals was 7 per group.

\section{Brain Tissue Experiment}

On day 30 , the animals were sacrificed with focused highenergy microwave irradiation, as it results in increased 
recovery of peptides (Mathé et al. 1990; Theodorsson et al. 1990). The brains were removed and dissected on ice into hypothalamus, frontal cortex, striatum, occipital cortex, and hippocampus, according to Glowinski and Iversen (1966). Samples were immediately frozen on dry ice, weighted and stored at $-80^{\circ} \mathrm{C}$ until further preparation.

\section{Peptide Extraction}

The peptide was extracted from tissues by homogenization with a Pooltron tissue homogenizer, followed by 5 min of ultrasonication and boiling for $10 \mathrm{~min}$ in $1 \mathrm{M}$ acetic acid. The homogenates were centrifuged at $6^{\circ} \mathrm{C}, 3000 \times$ $\mathrm{g}$ for $20 \mathrm{~min}$, the supernatants were collected and pellets reconstituted in distilled $\mathrm{H}_{2} \mathrm{O}$, followed by the identical sonication, boiling and centrifugation procedure. The two supernatants were pooled and freeze-dried and stored at $-80^{\circ} \mathrm{C}$ until radioimmunoassay (RIA). The samples were reconstituted in assay buffer before RIA.

\section{Microdialysis Experiment}

On day 28, while continuing on the same diet, the rats were implanted under barbiturate anesthesia (Mebumal, $60 \mathrm{mg} / \mathrm{ml}$ ) with a vertical probe in the VSTR with the incisor bar set at -3.3; AP +1.6, ML -1.3, DV -8.5 , measured from bregma according to Paxinos and Watson (1986). After implantation of the microdialysis probes, the animals were housed individually. Experiments were carried out in freely moving rats 48 $\mathrm{h}$ after surgery during the daylight period. The animals were perfused at a flow rate of $3 \mu \mathrm{l} / \mathrm{min}$ with sterile filtered modified Ringer's solution ( $\mathrm{pH}$ 7.2) containing: $147 \mathrm{mM} \mathrm{NaCl}, 2.9 \mathrm{mM} \mathrm{KCl}, 1.3 \mathrm{mM} \mathrm{CaCl}$, $1.0 \mathrm{mM} \mathrm{MgCl} 2$ and $0.9 \mathrm{mM} \mathrm{NaH}_{2} \mathrm{PO}_{4}$ with addition of $0.2 \%$ albumin chicken egg (Sigma) and $0.03 \%$ bacitracin (Sigma). Dialysis occurred through a semi-permeable membrane (AN 69 Hospal), having an active surface length of $3.0 \mathrm{~mm}$. After obtaining three baseline dialysate samples, collected every $60 \mathrm{~min}$, the animals received a subcutaneous (s.c.) injection (administered at a volume of $1 \mathrm{ml} / \mathrm{kg})$ of either saline $(0.9 \% \mathrm{NaCl})$ or $d$-amphetamine $(1.5 \mathrm{mg} / \mathrm{kg})$. After the injection five additional samples were collected. All samples were stored at $-80^{\circ} \mathrm{C}$ until RIA.

\section{NT Radioimmunoassay}

Neurotensin-LI in the tissue supernatants and dialysates was quantified by RIA using NT standard (Cat.No. 7351) and antiserum (Cat.No. 7351), both purchased from Peninsula Laboratories, UK, and ${ }^{125}$ I-labeled NT obtained from Amersham International, UK. The antiserum is directed toward the middle portion of the NT molecule and was used at a final dilution that provides $30 \%$ zero binding of the labeled NT. The assay was run in duplicates as follows: $25 \mu$ l standards (prepared in same buffers as samples) and samples were incubated at $4^{\circ} \mathrm{C}$ for $48 \mathrm{~h}$ with $100 \mu \mathrm{l}$ of antibody. Following this incubation, 100 $\mu l$ of labeled NT was added and the solution was incubated for an additional $24 \mathrm{~h}$. Free and antibody-bound NT were separated by $50 \mu \mathrm{l} \mathrm{Sac-Cel} \mathrm{(anti-rabbit} \mathrm{solid}$ phase second antibody coated cellulose suspension; IDS, Bolton, UK). Samples were left for $30 \mathrm{~min}$ at room temperature, the reaction was then blocked with $1 \mathrm{ml}$ distilled $\mathrm{H}_{2} \mathrm{O}$. After centrifugation at $3000 \times \mathrm{g}$ for 20 min at $4^{\circ} \mathrm{C}$, the supernatants were decanted and the pellets were counted in a $\gamma$ counter. The assay has a sensitivity of $1.95 \mathrm{fmol} / \mathrm{ml}$ and an $\mathrm{IC}_{50}$ of $67 \mathrm{fmol} / \mathrm{ml}$. The intra- and interassay coefficients of variation were $3 \%$ and $9 \%$, respectively.

\section{Plasma and Tissue Concentrations of Risperidone and Haloperidol}

Rats were randomly divided into four groups $(n=3$ animals/group) receiving the same treatment as in the tissue and microdialysis experiments. After 30 days, animals were sacrificed by guillotine, the serums were collected and the brains removed and dissected. Plasma and brain concentrations of haloperidol, risperidone and 9-OH risperidone were determined by high performance liquid chromatography (HPLC) by Janssen Pharmaceutica.

\section{Statistical Analysis}

The effects of drug treatments on brain tissue levels of NT (fmol/mg wet weight tissue + S.E.M.) were analyzed by 1-way (treatment: haloperidol, both doses of risperidone, control) analysis of variance (ANOVA) for each brain region (Figure 1). Significant effects revealed by the 1-way ANOVAs were further evaluated with the Student-Newman-Keuls test for multiple comparisons.

Dialysis data were calculated as percent change of basal concentrations, $100 \%$ being defined as the average of the last three baselines values before the injection (saline or $d$-amphetamine). The effects of treatments over time were analyzed by 2-way ANOVA (treatment 1: haloperidol, both doses of risperidone, control; treatment 2: saline or $d$-amphetamine) at each time point and 1-way ANOVA (time) for each group (Figure 3). Data are also presented as the average overall increases after injection (saline or $d$-amphetamine) and analyzed by 2-way ANOVA (treatment $1 \mathrm{X}$ treatment 2) (Figure 4). Basal NT-LI concentrations in the various treatment groups were evaluated by 1-way ANOVA (treatment: haloperidol, both doses of risperidone, control) (Figure 2). Significant effects revealed by the 2- or 1-way ANOVAs were further evaluated with the Student-Newman-Keuls test for multiple comparisons. 


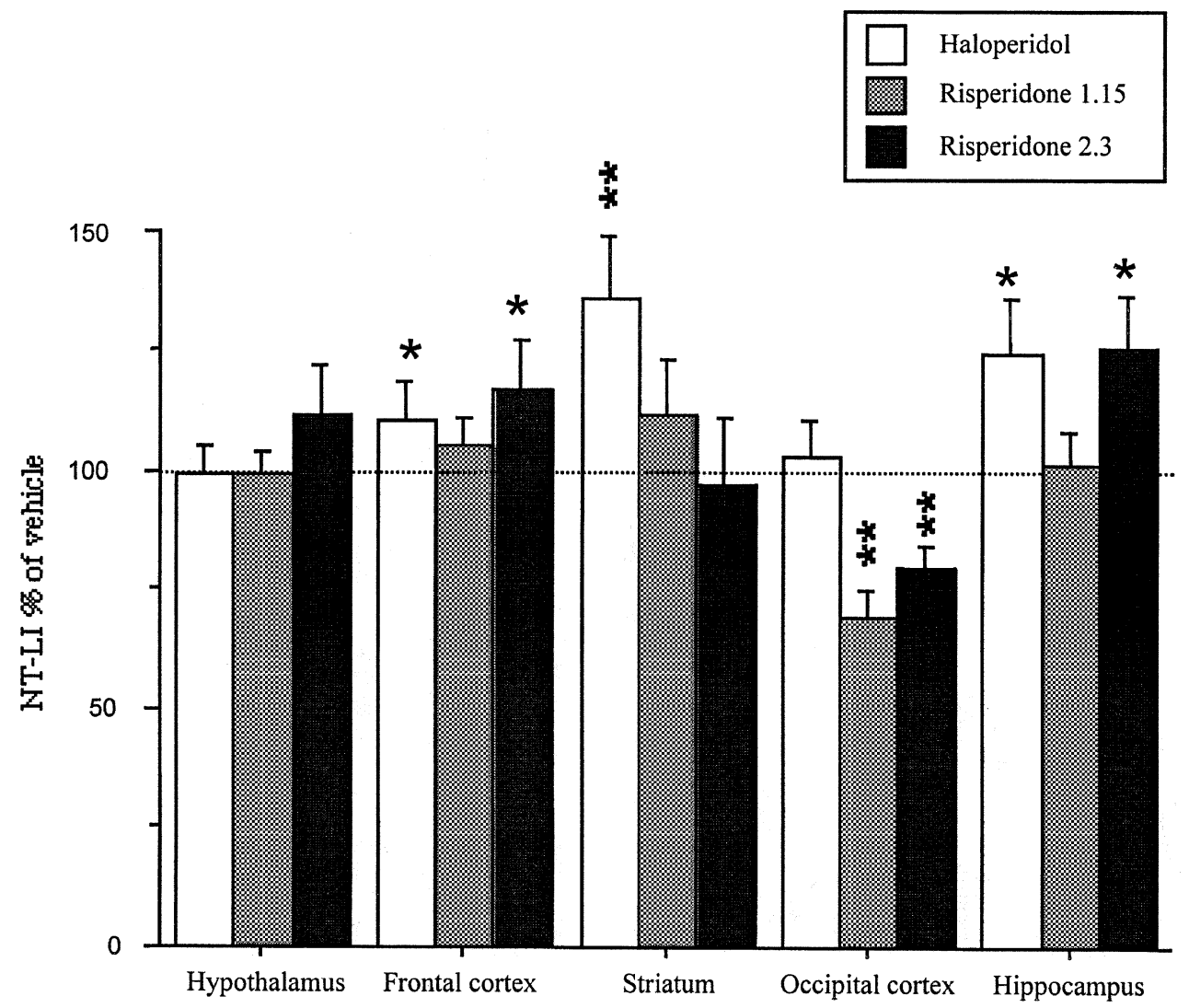

Figure 1. Effects of 30-day treatment with haloperidol or risperidone (1.15 or $2.3 \mathrm{mg} / 100 \mathrm{~g}$ food) on NT-LI concentrations in rat brain regions. Data (mean + S.E.M.) are expressed as percent change from the mean of the corresponding vehicle treated group. ${ }^{*} p<.05,{ }^{* *} p<.01$, as compared with vehicle (ANOVA followed by the Student-Newman-Keuls). $\mathrm{n}=10$ animals $/$ group.

\section{RESULTS}

\section{NT-LI in Brain Regions: Effects of Antipsychotic Drugs}

NT-LI was unevenly distributed among the brain regions studied. Hypothalamus had the highest concentration: $104.2 \pm 3.5$, followed by striatum $13.8 \pm 1.5$, frontal cortex $11.8 \pm 0.7$, occipital cortex $11.3 \pm 0.6$, and hippocampus $3.7 \pm 0.5$, expressed as mean $( \pm \mathrm{SEM}) \mathrm{fmol} / \mathrm{mg}$ wet weight tissue. As shown in Figure 1, haloperidol and the higher dose of risperidone increased NT-LI in the frontal cortex ( $p$ values $<.05$ ). In striatum, haloperidol increased NT-LI $(p<.01)$, while no effect of risperidone was found. In the occipital cortex, both doses of risperidone decreased NT-LI ( $p$ values $<0.01$ ), whereas no effect of haloperidol was detected. The NT-LI concentrations were increased in hippocampus by both haloperidol and the higher risperidone dose $(p$ values $<.05)$.

\section{NT-LI in Microdialysates from Ventral Striatum: Effects of Antipsychotic Drugs and d-Amphetamine}

The basal extracellular concentrations of NT-LI in vehicle treated animals were $194.6 \pm 28.4 \mathrm{fmol} / \mathrm{ml}$, prior to the injection. As shown in Figure 2, haloperidol and the higher dose of risperidone significantly decreased the basal extracellular levels of NT-LI (haloperidol $115.2 \pm$ $9.9 \mathrm{fmol} / \mathrm{ml}$, risperidone $136.0 \pm 13.0 \mathrm{fmol} / \mathrm{ml}$ ) ( $p$ values < .05). The lower dose of risperidone did not affect the basal outflow of NT-LI $(199.9 \pm 24.0 \mathrm{fmol} / \mathrm{ml})$ (Figure 2). Injection of saline had no effect on NT-LI release in either the vehicle (Figure 3), haloperidol or risperidone pretreated groups (data not shown). In contrast, administration of $d$-amphetamine in vehicle treated rats (Figure 3) resulted in a time-dependent, significant increase of NT-LI (120 min: $p<.01 ; 180 \mathrm{~min}: p<.01 ; 240$ min: $p<.01 ; 300$ min: $p<.05)$. Pretreatment with haloperidol or the higher risperidone dose abolished the stimulatory effect of $d$-amphetamine on NT-LI efflux (Figure 3). In animals treated with the lower risperidone dose, the action of $d$-amphetamine was also decreased (Figure 3). The overall changes in dialysate NT-LI concentrations are presented in Figure 4. Amphetamine significantly increased extracellular NT-LI in vehicle treated animals $(p<.01)$. Pretreatment with the lower dose of risperidone significantly $(p<.05)$ diminished the effect of $d$-amphetamine, while pretreatment with haloperidol and the higher risperidone dose abolished the $d$-amphetamine effects ( $p$ values $<.01$ ). 


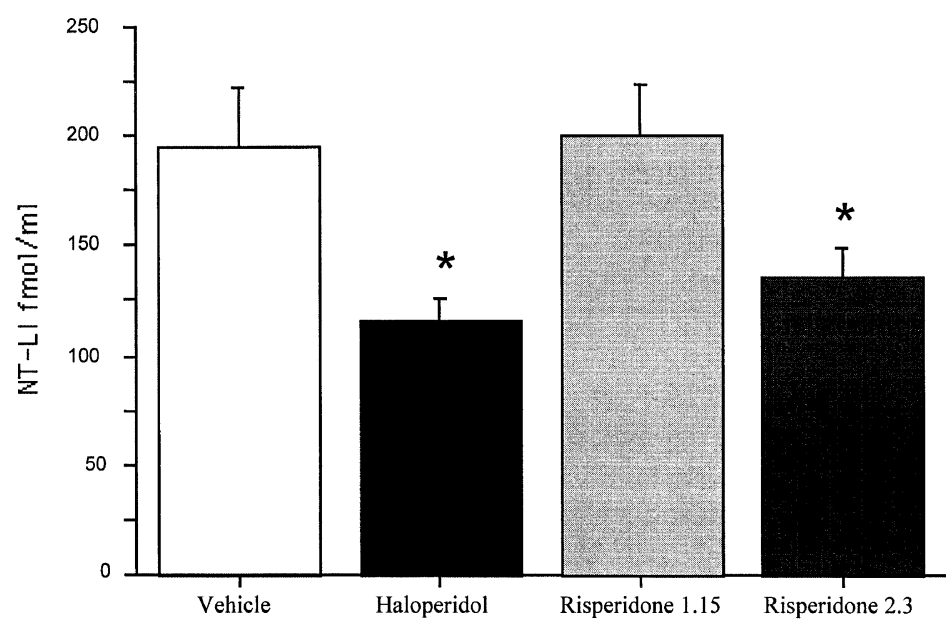

Figure 2. Basal dialysate concentrations of NT-LI in rat ventral striatum. Rats were pretreated with vehicle, haloperidol or risperidone (1.15 or $2.3 \mathrm{mg} /$ $100 \mathrm{~g}$ food). Data are presented as mean + S.E.M. $\mathrm{fmol} / \mathrm{ml}$ of the three baseline periods $(0-180 \mathrm{~min})$ for each pretreatment. ${ }^{*} p<.05$, compared with the vehicle pretreated group (ANOVA followed by the Student-Newman-Keuls). $\mathrm{n}=14$ animals/group.

In vehicle pretreated animals administration of $d$-amphetamine resulted in an increased locomotor activity, whereas in haloperidol or risperidone pretreated animals no stimulatory effect of $d$-amphetamine on behavior was observed (data not shown).

\section{Plasma and Tissue Concentrations of Haloperidol and Risperidone}

The mean plasma and tissue levels of haloperidol, risperidone and 9-OH-risperidone after administration of haloperidol (1.15 mg/100 $\mathrm{g}$ food) or risperidone (1.15 or 2.3 $\mathrm{mg} / 100 \mathrm{~g}$ food) are summarized in Table 1. Data are expressed as mean \pm SEM $\mathrm{ng} / \mathrm{g}$ in the brain regions and as $\mathrm{ng} / \mathrm{ml}$ in plasma. The number of animals was 1-3 per group. As expected, no haloperidol was detectable in animals receiving risperidone or vehicle, and no risperidone was detectable in animals receiving haloperidol or vehicle.

\section{DISCUSSION}

The present study shows that 30-day administration of haloperidol and risperidone resulted in drug and brain

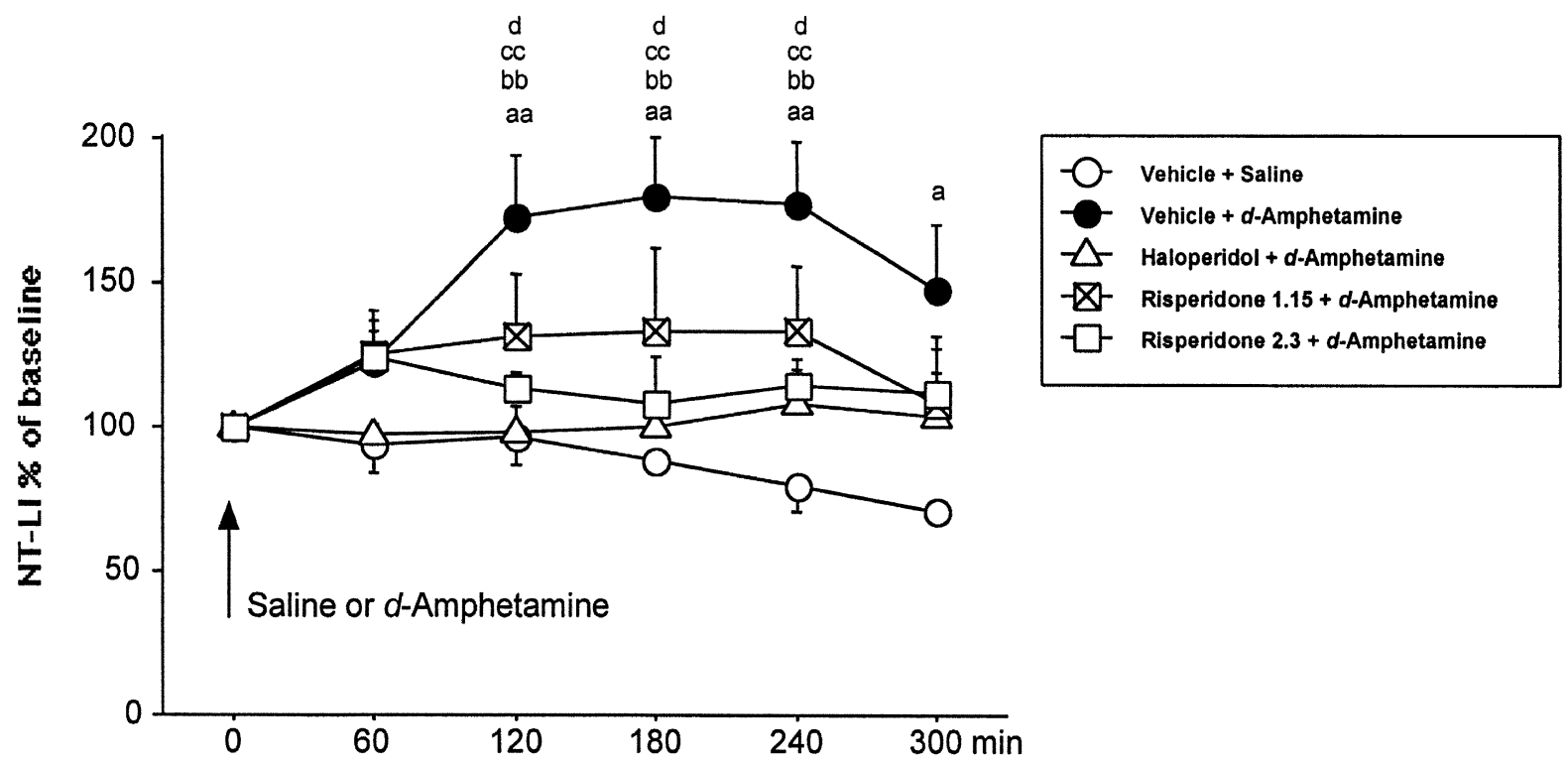

Figure 3. Changes in dialysate NT-LI concentrations in rat ventral striatum after a single injection of saline or $d$-amphetamine in rats pretreated with vehicle, haloperidol or risperidone (1.15 or $2.3 \mathrm{mg} / 100 \mathrm{~g}$ food). The arrow indicates time of injection. Data are presented as mean \pm SEM percent changes of baseline values that were obtained prior to the injection. (a) $p<.05$, (aa) $p<.01$, comparisons between (vehicle + saline) and (vehicle + amphetamine), (bb) $p<.01$, comparisons between (haloperidol + amphetamine) and (vehicle + amphetamine), (cc) $p<.01$, comparisons between (risperidone $2.3+$ amphetamine) and (vehicle + amphetamine), (d) $p<.05$, comparisons between (risperidone $1.15+$ amphetamine) and (vehicle + amphetamine), (ANOVA followed by the Student-Newman-Keuls). $\mathrm{n}=7$ animals/group. 


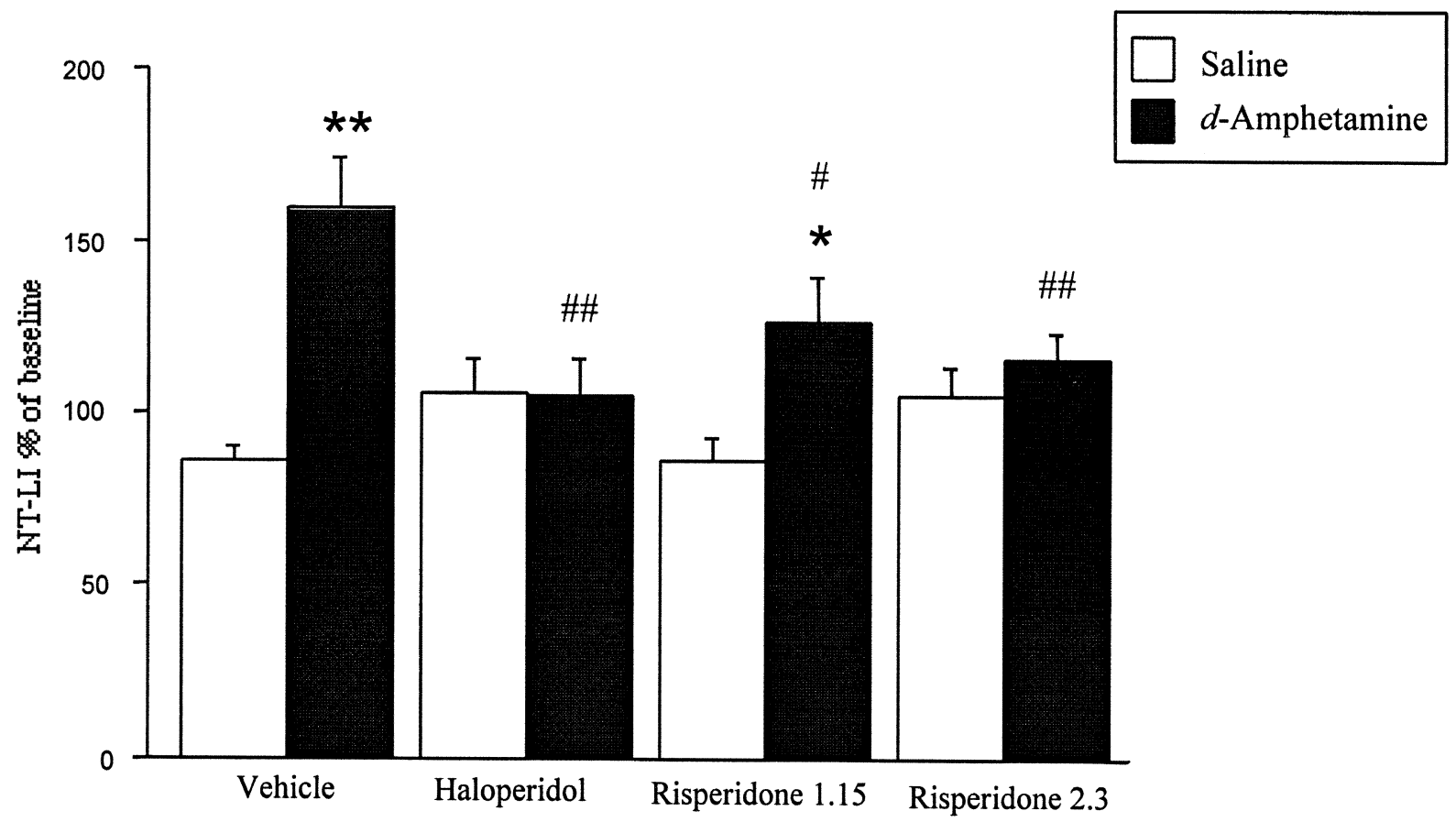

Figure 4. Changes in dialysate NT-LI concentrations in rat ventral striatum after a single injection of saline or $d$-amphetamine in rats pretreated with vehicle, haloperidol or risperidone (1.15 or $2.3 \mathrm{mg} / 100 \mathrm{~g}$ food). Each column represents the overall (60-300 min after the injection) mean + S.E.M. percent change from three baseline values that were obtained prior to the injection. ${ }^{*} p<.05,{ }^{* *} p<.01$, as compared with the groups injected with saline, $\# p<.05$, \#\# $p<.01$ as compared with the vehicle- $d$-amphetamine treated group (ANOVA followed by the Student-Newman-Keuls). $\mathrm{n}=7$ animals $/$ group.

region selective changes in NT-LI levels. Thus, NT-LI concentrations were increased by haloperidol in the frontal cortex, striatum and hippocampus, and by a higher risperidone dose in the frontal cortex and hippocampus. Both doses of risperidone decreased NT-LI levels in the occipital cortex. Several studies have demonstrated that neuroleptic drugs increase tissue concentrations of NT in both the striatum and the nucleus accumbens (Eggerman and Zahm 1988; Frey et al. 1988; Huang and Hanson 1997; Levant et al. 1991; Merchant and Dorsa 1993; Merchant et al. 1992, 1994a). On the other hand, the atypical antipsychotic clozapine increases NT concentrations only in the nucleus accumbens (Merchant and Dorsa 1993). Similar results were obtained when the NT/neuromedin (N) mRNA expression was assessed in these brain regions in response to haloperidol and clozapine (Merchant and Dorsa 1993; Merchant et al. 1992, 1994b). Consequently, a tentative conclusion is that the haloperidol induced NT-LI increase in striatum might be associated with the extrapyramidal side effects (EPS) produced by classical neuroleptic drugs. The findings that chronic treatment with haloperidol but not clozapine increased NT-LI in the dorsal striatum (Kilts et al. 1988), and that chronic risperidone treatment does not affect NT mRNA levels in the striatum (Mijnster et al. 1995) further support such an assumption. One likely explanation for these apparent discrepancies is different dissection techniques and, as already Gygi et al. (1994) commented, that "NT systems throughout the entire striatum and nucleus accumbens do not respond in a homogenous manner" to antipsychotic drug administration. Whether these biochemical effects underlie risperidone's favorable clinical profile as far as EPS (Marder 1998) is presently not known.

The findings that both haloperidol and risperidone increased NT-LI concentrations in the frontal cortex and the hippocampus is likely to be relevant for their antipsychotic efficacy. In this regard, other studies have reported either an increase (Goedert et al. 1985) or no change (Levant et al. 1991) in NT-LI in the frontal cortex, or even a decrease in NT in the medial prefrontal cortex (Kilts et al. 1988), after chronic treatment with haloperidol. These different results, including our own, may be due to differences in the methodology, such as the region of the frontal cortex assessed and the neuroleptic regimen followed. Nevertheless, in view of the presumed frontal cortex hypodopaminergic state in schizophrenia, the NT-DA interactions and the hypothesis that NT is an endogenous antipsychotic, our results that both haloperidol and risperidone increase NT in frontal cortex seem plausible. Supporting this hypothesis is our recent finding that chronic treatment with olanzapine also elevates NT in the rat frontal cortex (Gruber et al. 2001). 
Table 1. Haloperidol and Risperidone Concentrations in Plasma and Brain Regions

\begin{tabular}{lccr}
\hline & Haloperidol & Risperidone 1.15 & Risperidone 2.3 \\
\hline Plasma & $1.61 \pm 0.6$ & $13.0 \pm 3.0$ & $19.4 \pm 1.5$ \\
Hypothalamus & $104.3 \pm 17.7$ & $4.4 \pm 0.7$ & $8.2 \pm 1.8$ \\
Frontal cortex & $78.8 \pm 12.3$ & $4.5 \pm 0.3$ & $3.67 \pm 0.7$ \\
Striatum & $86.0 \pm 21.0$ & $3.1 \pm 1.0$ & $3.0 \pm 0.4$ \\
Occipital cortex & $92.2 \pm 17.9$ & $2.5 \pm 0.3$ & $3.0 \pm 0.4$ \\
Hippocampus & $199.7 \pm 123.3$ & 3.1 & 0.7 \\
\hline
\end{tabular}

Haloperidol and total active moiety of risperidone (risperidone +9 -hydroxy-risperidone) concentrations in plasma and brain regions following 30 day treatment with haloperidol $(1.15 \mathrm{mg} / 100 \mathrm{~g}$ food) or risperidone ( 1.15 or $2.3 \mathrm{mg} / 100 \mathrm{~g}$ food). Data are expressed as mean \pm S.E.M. $\mathrm{ng} / \mathrm{ml}$ in plasma and as $\mathrm{ng} / \mathrm{g}$ in the brain regions. $\mathrm{N}=1-3$ animals/group.

In general there is a paucity of data on effects of antipsychotic and other psychoactive drugs on the occipital cortex. However, a few published studies show effects on some neuropeptides and neurotrophic factors BDNF and NGF as well as dopamine receptor binding in the occipital cortex (Angelucci et al. 2000a,b; Lidow and Goldman-Rakic 1994). Although the functional significance of NT changes is not clear, it might be of relevance that two other neuropeptides interacting with the dopaminergic system, Calcitonin gene-related peptide (CGRP) and substance $\mathrm{P}$ are also decreased by risperidone and unaffected by haloperidol (Gruber and Mathé 1999). In view of interactions between working memory, a prefrontal cortex task, and visual attention tasks, localized in the occipital cortex (de Fockert et al. 2001; Supèr et al. 2001) and the observations that these processes are deranged in schizophrenia, selective effects of risperidone on NT, CGRP and substance P might constitute biological correlates of its beneficial effects on cognitive processes.

As far as the microdialysis results, haloperidol and the higher dose of risperidone decreased basal extracellular NT-LI levels in the VSTR. These findings are in line with results showing decreased extracellular NT-LI concentrations in the nucleus accumbens and the caudate putamen following treatment with eticlopride, a DA- $\mathrm{D}_{2}$ receptor antagonist (Wagstaff et al. 1996a). In line with our striatal tissue results, Wagstaff et al. (1996a) and Merchant and Dorsa (1993), have also shown that DA-D 2 antagonists increase NT mRNA and NT-LI tissue content in striatum. Taken together, the data indicate that antipsychotic drugs increase NT gene expression and subsequently NT concentrations in selected brain structures of central relevance for dopaminergic function. The decreased NT-LI concentrations in microdialysates could reflect either a decreased release or increased breakdown of NT. The former is consistent with findings of elevated NT levels, while the latter possibility is supported by reports that antipsychotics alter NT fragmentation in tissue experiments in vitro (Konkoy et al. 1994). However, there are some data showing that chronic, but not acute, administration of haloperidol increased the basal NT-LI release in both the caudate nucleus and the nucleus accumbens (Radke et al. 1998). This seeming discrepancy with our findings could be due to methodological differences, such as different probe-placement and tissue sampling as well as different RIA method. In conclusion, it is conceivable that the decreased NT-LI extracellular concentrations in the VSTR caused by haloperidol and risperidone might reflect their shared antipsychotic property.

In the present study, single injection of $d$-amphetamine markedly increased extracellular NT-LI concentration in VSTR. In a previous experiment, similar administration of $d$-amphetamine or PCP increased extracellular concentrations of both NT-LI and DA in the VSTR and medial prefrontal cortex, although the effect of $d$-amphetamine on NT-LI in the VSTR did not attain statistical significance (Hertel et al. 1996). This may be due to the differences in experimental procedures, including use of different NT antibodies in RIA. Our results are in line with findings that other psychostimulant drugs, e.g. methamphetamine, also increase NT efflux in both the striatum and the nucleus accumbens (Wagstaff et al. 1996b). Although the mechanism underlying the stimulatory effects of psychostimulant drugs on NT efflux is not fully elucidated, it is likely due to an enhanced DA release and stimulation of DA receptors. Thus, administration of quinpirole, a DA- $\mathrm{D}_{2}$ agonist increases extracellular NT efflux in the nucleus accumbens and pretreatment with eticlopride, a DA- $\mathrm{D}_{2}$ receptor antagonist diminishes the methamphetamineinduced increase in NT efflux (Wagstaff et al. 1996a,b). Our results that haloperidol and risperidone diminished the effect of $d$-amphetamine on NT efflux are in line with the above findings. Incidentally, although we did not systematically monitor locomotor activity during the microdialysis experiments, it was clear that the behavioral effect of $d$-amphetamine was markedly diminished by haloperidol or risperidone. In this regard, it is relevant that both typical and atypical antipsychotics block the induction of behavioral sensitization to amphetamine as well as associated NT/N mRNA responses in the nucleus accumbens (Meng et al. 1998). Thus, it appears that antipsychotic drugs counteract the behavioral as well as the biochemical effects of psychostimulants both on dopaminergic neu- 
rotransmission and on NT. Lastly, the plasma and tissue concentrations of haloperidol and risperidone were comparable to those attained in previous studies (Sunderland and Cohen 1987; Aravagiri et al. 1998) and deemed to achieve a high degree of $\mathrm{DA}-\mathrm{D}_{2}$ receptor occupancy (Schotte et al. 1996).

In summary, the present work shows that both haloperidol and risperidone affect tissue concentrations of NT-LI in distinct regions of the brain, as well as the efflux of NT-LI in VSTR. Injection of $d$-amphetamine increases NT-LI release in the VSTR, an effect that was abolished by antipsychotic pretreatment. These data may have significant implications in understanding the role of brain NT in schizophrenia and in antipsychotic drug action.

\section{ACKNOWLEDGMENTS}

Supported by the Swedish Medical Research Council, grant 10414, Karolinska Institutet and Janssen Research Foundation. We thank B. Eriksson and Dr. W. Coussement, Janssen Pharmaceutica, Sweden and Belgium, respectively, for haloperidol and risperidone measurements in serum and brain and for generously preparing the food pellets.

\section{REFERENCES}

Angelucci F, Aloe L, Gruber SHM, Fiore M, Mathé AA (2000a): Chronic antipsychotic treatment selectively alters nerve growth factor and neuropeptide $\mathrm{Y}$ immunoreactivity and the distribution of choline acetyl transferase in rat brain regions. Int J Neuropsychopharmacol 3:13-25

Angelucci F, Mathé AA, Aloe L (2000b): Brain-derived neurotrophic factor and tyrosine kinase receptor TrkB in rat brain are significantly altered after haloperidol and risperidone administration. J Neurosci Res 15 60:783-794

Aravagiri M, Marder SR, Wirshing D, Wirshing WC (1998): Plasma concentrations of risperidone and its 9-hydroxy metabolite and their relationship to dose in schizophrenic patients: simultaneous determination by a high performance liquid chromatography with electrochemical detection. Pharmacopsychiat 31:102-109

Augood SJ, Kiyama H, Faull RLM, Emson PC (1991): Differential effects of acute dopaminergic D1 and D2 receptor antagonists on proneurotensin mRNA expression in rat striatum. Mol Brain Res 9:341-346

Azzi M, Betancur C, Sillaber I, Spanagel R, Rostène W, Bérod A (1998): Repeated administration of the neurotensin receptor antagonist SR 48692 differentially regulates mesocortical and mesolimbic dopaminergic systems. J Neurochem 71:1158-1167

Betancur C, Rostène W, Bérod A (1997): Chronic cocaine increases neurotensin gene expression in the shell of the nucleus accumbens and in discrete regions of the striatum. Mol Brain Res 44:334-340

Blaha CD, Coury A, Fibiger HC, Phillips AG (1990): Effects of neurotensin on dopamine release and metabolism in the rat striatum and nucleus accumbens: cross-valida- tion using in vivo voltammetry and microdialysis. Neuroscience 34:699-705

Bogerts B (1999): The neuropathology of schizophrenic diseases: historical aspects and present knowledge. Eur Arch Psychiatry Clin Neurosci 249: Suppl 4, 2-13

Breslin NA, Suddath RL, Bissette G, Nemeroff CB, Lowrimore P, Weinberger DR (1994): CSF concentrations of neurotensin in schizophrenia: an investigation of clinical and biochemical correlates. Schizophr Res 12:35-41

Cadet JL, Kayoko K, Przedborski S (1991): Bilateral modulation of $\left[{ }^{3} \mathrm{H}\right]$ neurotensin binding by unilateral intrastriatal 6-hydroxydopamine injections: Evidence from a receptor autoradiografic study. Brain Res 564:37-44

Carraway RE, Leeman SE (1973): The isolation of a new hypotensive peptide, neurotensin, from bovine hypothalami. J Biol Chem 248:6854-6861

Castel MN, Morino P, Dagerlind Å, Hökfelt T (1994): Upregulation of neurotensin mRNA in the rat striatum after acute methamphetamine treatment. Eur J Neurosci 6:646-656

Chapman MA, See RE, Bissette G (1992): Neurotensin increases extracellular striatal dopamine levels in vivo. Neuropeptides 22:175-183

Csernansky JG, Murphy GM, Faustman WO (1991): Limbic/ mesolimbic connections and the pathogenesis of schizophrenia. Biol Psychiat 15 30:383-400

de Fockert JW, Rees G, Frith CD, Lavie N (2001): The role of working memory in visual selective attention. Science 291:1803-6

Eggerman KW, Zahm DS (1988): Numbers of neurotensinimmunoreactive neurons selectively increased in rat ventral striatum following acute haloperidol administration. Neuropeptides 11:125-132

Ervin GN, Birkemo LS, Nemeroff CB, Prange AJ Jr (1981): Neurotensin blocks certain amphetamine-induced behaviours. Nature 291:73-76

Frey P, Lis M, Coward DM (1988): Neurotensin concentrations in rat striatum and nucleus accumbens: Futher studies of their regulation. Neurochem Int 12:33-38

Fuxe K, O'Connor WT, Antonelli T, Osborne PG, Tanganelli S, Agnati LF, Ungerstedt U (1992): Evidence for a substrate of neuronal plasticity based on pre- and postsynaptic neurotensin-dopamine receptor interactions in the neostriatum. Proc Natl Acad Sci 89:5591-5595

Glowinski J, Iversen LL (1966): Regional studies of catecholamines in the rat brain: The disposition of $(3 \mathrm{H})$ norepinerphine, $(3 \mathrm{H})$ dopamine and $(3 \mathrm{H})$ dopa in various regions of the brain. J Neurochem 13:655-669

Goedert M, Iversen SD, Emson PC (1985): The effects of chronic neuroleptic treatment on neurotensin-like immunoreactivity in the rat central nervous system. Brain Res 335:334-336

Grace AA, Moore H (1998): Regulation of information flow in the nucleus accumbens: A model for the pathophysiology of schizophrenia. In Lenzenweger MF, Dworkin RH (eds), Origins and Development of Schizophrenia: Advances in Experimental Psychopathology. Washington, DC, American Psychological Association Press, pp 123-157

Gray JA, Feldon J, Rawlins JNP, Hemsley DR, Smith AD (1991): The neuropsychology of schizophrenia. Behav Brain Sci 14:1-84

Gruber SHM, Mathé AA (1997): Antipsychotics haloperidol 
and risperidone and psychotomimetic amphetamine affect neuropeptides and monoamines in brain. Proc 27th Ann Meet Soc Neurosci 23:120

Gruber SHM, Mathé AA (1999): Effects of amphetamine on brain peptides in haloperidol or risperidone pretreted rats. Nord J Psychiatry 53:97

Gruber SHM, Nomikos GG, Angelucci F, Mathé AA (2001): Effect of chronic and acute olanzapine on neurotensin levels in rat brain tissue regions and release in ventral striatum. 7th World J Biological Psychiatry, Berlin, Vol 2, Suppl 1, Abstract: O048-01

Gygi SP, Gibb JW, Hanson GR (1994): Differential effects of antipsychotic and psychotomimetic drugs on neurotensin systems of discrete extrapyramidal and limbic regions. J Pharmacol Exp Ther Jul 270:192-197

Hanson GR, Smiley P, Johnson M, Letter A, Bush L, Gibb JW (1989): Response by the neurotensin systems of the basal ganglia to cocaine treatment. Eur J Pharmacol 160: 23-30

Hertel P, Mathé JM, Nomikos GG, Iurlo M, Mathé AA, Svensson TH (1996): Effects of D-amphetamine and phencylidine on behavior and extracellular concentrations of neurotensin and dopamine in the ventral striatum and the medial prefrontal cortex of the rat. Behav Brain Res 72:103-114

Huang W, Hanson GR (1997): Differential effect of haloperidol on release of neurotensin in extrapyramidal and limbic systems. Eur J Pharmacol 332:15-21

Hökfelt T, Everitt BJ, Theodorsson-Norheim E, Goldstein M (1984): Occurrence of neurotensin-like immunoreactivity in subpopulations of hypothalamic, mesencephalic and medullary catecholamine neurons. J Comp Neurol 222:543-559

Joliceur FB, Gange MA, Rivest R, Drumheller A, St Pierre S (1993): Atypical neuroleptic-like behavioral effects of neurotensin. Brain Res Bull 32:487-491

Kalivas PW (1993): Neurotransmitter regulation of dopamine neurons in the ventral tegmental area. Brain Res Rev 18:75-113

Kasckow J, Nemeroff CB (1991): The neurobiology of neurotensin: focus on neurotensin-dopamine interactions. Reg Peptides 36:153-164

Kilts CD, Anderson CM, Bissette G, Ely TD, Nemeroff CB (1988): Differential effects of antipsychotic drugs on the neurotensin content of discrete rat brain nuclei. Biochem Pharmacol 37:1547-1554

Kinkead B, Shahid S, Owens MJ, Nemeroff CB (2000): Effects of acute and subchronic administration of typical and atypical drugs on the neurotensin system of the rat brain. J Pharmacol Exp Ther 295:67-73

Konkoy CS, Waters SM, Davis TP (1994): Acute administration of neuroleptics decreases neurotensin metabolism on intact, regional rat barin slices. J Pharmacol Exp Ther 269:555-563

Lambert PD, Gross R, Nemeroff CB, Kilts CD (1995): Anatomy and mechanisms of neurotensin-dopamine interactions in the central nervous system. Ann N Y Acad Sci 757:377-389

Letter AA, Merchant KM, Gibb JW, Hanson GR (1987): Effect of methamphetamine on neurotensin concentrations in rat brain regions. J Pharmacol Exp Ther 241: 443-447

Levant B, Bissette G, Widerlöv E, Nemeroff CB (1991): Alter- ations in regional brain neurotensin concentrations produced by atypical antipsychotic drugs. Reg Peptides 32:193-201

Levant B, Merchant KM, Dorsa DM, Nemeroff CB (1992): BMY 14802, a potential antipsychotic drug, increases expression of proneurotensin mRNA in the rat striatum. Mol Brain Res 12:279-284

Lidow MS, Goldman-Rakic PS (1994): A common action of clozapine, haloperidol, and remoxipride on D1- and D2dopaminergic receptors in the primate cerebral cortex. Proc Natl Acad Sci USA 91:4353-4356

Lindström LH, Widerlöv E, Bisette G, Nemeroff C (1988): Reduced CFS neurotensin concentration in drug free schizophrenic patients. Schizophr Res 1:55-59

Marder SR (1998): Antipsychotic medication. In Schatzberg AF, Nemeroff CB (eds), Textbook of Psychopharmacology, 2nd edition. Washington, DC, American Psychological Association Press, pp 309-321

Mathé AA, Stenfors C, Brodin E, Theodorsson E (1990): Neuropeptides in brain: Effects of microwave irradiation and decapitation. Life Sci 46:287-293

Meng ZH, Feldpaush DL, Merchant KM (1998): Clozapine and haloperidol block the induction of behavioral sensitization to amphetamine and associated genomic responses in rats. Mol Brain Res 61:39-50

Merchant KM, Bush LG, Gibb JW, Hanson GR (1989): Dopamine D2 receptors exert tonic regulation over discrete neurotensin systems of the rat brain. Brain Res 500:21-29

Merchant KM, Dobner PR, Dorsa DM (1992): Differential effects of haloperidol and clozapine on neurotensin gene transcription in rat neostriatum. J Neurosci 12:652-663

Merchant KM, Dorsa DM (1993): Differential induction of neurotensin and $c$-fos gene expression by typical versus atypical antipsychotics. Proc Natl Acad Sci 90:3447-3451

Merchant KM, Dobie DJ, Filloux FM, Totzke M, Aravagiri M, Dorsa DM (1994a): Effects of chronic haloperidol and clozapine treatment on neurotensin and c-fos mRNA in rat neostriatal subregions. J Pharmacol Exp Ther 271:460-471

Merchant KM, Hanson GR, Dorsa DM (1994b): Induction of neurotensin and c-fos mRNA in distinct subregions of rat neostriatum after acute methamphetamine: Comparison with acute haloperidol effects. J Pharmacol Exp Ther 269:806-812

Merchant KM, Miller MA (1994): Coexpression of neurotensin and c-fos mRNAs in rat neostriatum neurons following acute haloperidol. Mol Brain Res 23:271-277

Mijnster MJ, Docter GJ, Voorn P (1995): Risperidone does not elevate neurotensin mRNA in rat nucleus accumbens and caudate-putamen. Neuroreport 6:162209162212

Nemeroff CB, Levant B, Myers B, Bissette G (1992): Neurotensin: antipsychotic drugs, and schizophrenia. Ann NY Acad Sci 668:147-156

Paxinos G, Watson C (1986): The rat brain in stereotaxic coordinates. San Diego, Academic Press

Quirion R (1983): Interactions between neurotensin and dopamine in the brain: An overview. Peptides 4:609-614

Radke JM, Owens MJ, Ritchie JC, Nemeroff CB (1998): Atypical antipsychotic drugs selectively increase neurotensin 
efflux in dopamine terminal regions. Proc Natl Acad Sci 95:11462-11464

Robledo P, Maldonado R, Koob GF (1993): Neurotensin injected into the nucleus accumbens blocks the psychostimulant effects of cocaine but does not attenuate cocaine self-administration in the rat. Brain Res 622: 105-112

Sharma RP, Janicak PG, Bissette G, Nemeroff CB (1997): CSF neurotensin concentrations and antipsychotic treatment in schizophrenia and schizoaffective disorders. Am J Psychiatry 154:1019-1921

Schotte A, Janssen PFM, Gommeren W, Luyten WHML, Van Gompel P, Lesage AS, De Loore K, Leysen JE (1996): Risperidone compared with new and reference antipsychotic drugs: in vitro and in vivo receptor binding. Psychopharmacol 124:57-73

Steinberg R, Brun P, Souilhac J, Bougault I, Leyris R, Le Fur G, Soubrie P (1995): Neurochemical and behavioural effects of neurotensin vs [D-Tyr11] neurotensin on mesolimbic dopaminergic function. Neuropeptides 28: 43-50

Sunderland T, Cohen BM (1987): Blood to brain distrubution of neuroleptics. Psychiatry Res 20:299-305
Supèr H, Spekreijse H, Lamme VAF (2001): A neural correlate of working memory in the monkey primary visual cortex. Science 293:120-124

Theodorsson E, Stenfors C, Mathé AA (1990): Microwave irradiation increases recovery of neuropeptides from brain tissues. Peptides 11:1191-1197

Wagstaff JD, Gibb JW, Hanson GR (1996a): Dopamine $\mathrm{D}_{2}$ receptors regulate neurotensin release from nucleus accumbens and striatum as measured by in vivo microdialysis. Brain Res 721:196-203

Wagstaff JD, Gibb JW, Hanson GR (1996b): Microdialysis assessment of methamphetamine-induced changes in extracellular neurotensin in the striatum and nucleus accumbens. J Pharmacol Exp Ther 278:547-554

Weinberger DR, Lipska BK (1995): Cortical maldevelopment, anti-psychotic drugs, and schizophrenia: a search for common ground. Schizophr Res 16:87-110

Widerlöv E, Lindström LH, Besev G, Manberg PJ, Nemeroff CB, Breese GR, Kizer JS, Prange AJ Jr (1982): Subnormal CSF levels of neurotensin in a subgroup of schizophrenic patients: normalization after neuroleptic treatment. Am J Psychiatry 139:1122-1126 